\title{
Comparison of Parameters of Automatic Milking in Selected Countries in European Union and United States
}

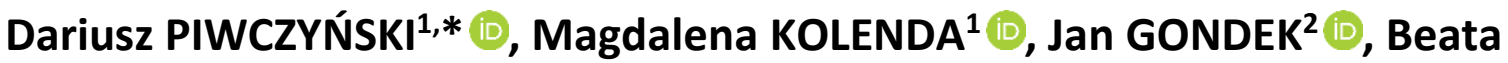 \\ SITKOWSKA ${ }^{1}$ (D)
}

\author{
${ }^{1}$ Department of Animal Biotechnology and Genetics, UTP University of Science and Technology; Mazowiecka 28, \\ 85-164 Bydgoszcz, Poland. \\ ${ }^{2}$ Lely East Sp. z o. o.; Pocztowa 2, 86-065, Łochowo, Poland. \\ *Corresponding author
}

\section{Article History}

Received: 20 November 2020

Accepted: 26 March 2021

First Online: 15 April 2021

\section{Corresponding Author}

E-mail: darekp@utp.edu.pl

\section{Keywords}

Automatic milking system

Milking parameters

Dairy cows

\begin{abstract}
The aim of this study was to compare selected parameters of automatic milking in various European Union countries and United States recorded between 2018 and 2020. Statistical analysis showed highly significant effect of country on all tested milking parameters. It was noted that i.e. the average number of cows per one robot, depending on country, ranged between 51.49 (the Netherlands) and 60.03 (Germany). Cows were milked on the average 2.50 (France) -2.83 (Latvia) per day, with milking speed ranging from $2.30 \mathrm{~kg} / \mathrm{min}$ (Lithuania) to 2.99 $\mathrm{kg} / \mathrm{min}$ (US). Daily milk yield obtained from one cow ranged from $25.12 \mathrm{~kg}$ (Lithuania) to $34.11 \mathrm{~kg}$ (US), while milk efficiency from 1.44 (Lithuania) to 1.77 $\mathrm{kg} / \mathrm{min}$ (US). Results also showed that the daily milk yield from one robot ranged from $1351 \mathrm{~kg}$ (Latvia) to $1930 \mathrm{~kg}$ (US). The statistical differences between the milking parameters in the compared countries may be the result of the diversified genetic potential of milked cows and the diversity of the feed base.
\end{abstract}

\section{Introduction}

Automatic milking system (AMS) that may be used to milk dairy cattle is in the use from the year 1992 back then the first robot was launched by Lely in the Netherlands (Nixon et al., 2009). Since then the interest in the automatic milking of cows is systematically growing. In 1998 an estimated number of farms with AMS worldwide was 250, in 2009 it was over 8 ths while in 2015 over 14 ths (de Koning \& Van der Vorst, 2002; de Koning, 2010; Taing, 2016). Salfer et al. (2017) estimated that in 2017 over 35 ths AMS operated all over the world. Today, the number of only Lely robot milkers exceeds 30 ths worldwide (Lely International, 2019). The dynamics of the growing number of AMS installations, that may be observed nowadays, may result mainly from the deepening deficit of qualified employees, as well as the beneficial effect of robotization of milking on the level of milking parameters (Brzozowski et al., 2018; Piwczyński et al., 2020b; Sitkowska et al., 2020). The results of numerous studies suggest that the increase in milk yield after the AMS installation, even up to $20 \%$, is directly caused by the increased number of milkings performed by the cow during the day (Rotz et al., 2003; Österman et al., 2005). Czerniawska-Piątkowska et al., (2012) noted the increase in the number of milkings from 2 to 4 times a day, which resulted in an increse of milk yiled in 305day lactation by $1160 \mathrm{~kg}$. In the previous research by the authors of this study, it was shown that cows in AMS barns in selected Eropean Union (EU) and United States (US) countries milk on average from 2.50 to 2.73 per day (Piwczyński et al., 2020a). At the same time, in the latest research, conducted on a vast dataset, it was found that the change of the milking system from conventional to automatic resulted in an increase in the yield of cows in the first (+ $1078 \mathrm{~kg}$ ) and the second (+ $1182 \mathrm{~kg}$ ) standardised 305-day lactation (Piwczyński et al., 2020b). The beneficial effect of changing the milking system was also demonstrated in terms of the 
registered fertility traits (Brzozowski et al., 2018; Piwczyński et al., 2020b). It should be emphasized, however, that not in all herds covered by the study the effect of changing the milking system in terms of functional and production features was beneficial for the breeder (Brzozowski et al., 2018; Piwczyński et al., 2020b). Sitkowska et al. (2015) reported that the increase in milk yield on farms equipped with AMS is possible, but it depends on a number of factors related to the milk production process. On the other hand, Bogucki et al. (2014) noted that the beneficial effect of robotization of milking increased with the passage of time from the moment of AMS installation.

According to Tse et al. (2017), the AMS installation brings several benefits to farmers, including: higher daily milking frequency and milk production; better health and improvement of the herd's fertility rates, the possibility of better management of the herd based on collected information, lower requirement for manpower and greater work flexibility; better quality of life for breeders. AMS may record over 100 milking parameters (Lely International, 2019). Wethal and Heringstad (2019), who performed the study on Norwegian Red cattle, stated that the new parameters recorded by AMS (such as box time, average flow rate etc.) and which cannot be easily recorded in the conventional milking system (CMS), could be included in breeding programs.

The aim of this study was to compare selected parameters of automatic milking (monthly reports) in various European Union countries and United States recorded between January 2018 and October 2020.

\section{Materials and Methods}

The present study included data recorded between $1^{\text {st }}$ January 2018 and $31^{\text {st }}$ October 2020 by data recording system by Lely. The following data was gathered: Average number of robots per herd (no.), Number of cows per robot (no.), Daily milk yield per robot (kg), Robot's free time $(\% / 24 \mathrm{~h})$, Average days in milk (days), Daily milking frequency (no./cow), Daily number of refusals (no./cow), Daily number of failed milking (no./cow), Box time - time spent by a cow in the robot during one visit (s), Milking speed ( $\mathrm{kg} / \mathrm{min})$, Daily milk yield per cow (kg), Fat content (\%), Protein content (\%), Rumination time (min./24h) and Consumption of concentrated fodder per $100 \mathrm{~kg}$ of milk (kg). The accumulated data were recorded in the Czech Republic (CZ), France (FR), Germany (DE), Italy (IT), Latvia (LV), Lithuania (LT), the Netherlands (NL), Poland (PL) and the United States (US). In total, the results recorded approximately by 9400 robots, distributed in 7000 herds and concerning the productivity of 520000 cows were analysed. Data was analysed with the use of twoway analysis of variance with the following linear model: $y_{i j k}=\mu+c_{i}+r_{j}+(c r)_{i j}+e_{i j k}$, where: $y_{i j k}-$ registered value of a variable, $\mu$-group average, $c_{i}$ - effect of $i^{\text {th }}$ country, $r_{j}$ - effect of $j^{\text {th }}$ year of milking, $(c r)_{i j}-$ country $\times$ milking year interaction, $\mathrm{e}_{\mathrm{ijk}}$ - random error.

The significance of differences between countries was determined using the Scheffé test. A statistical analysis of the collected numerical material was carried out using the SAS v. 9.4 software (SAS Institute Inc., 2014).

\section{Results and Discussion}

Results showed a highly significant impact of the origin country of milked cows on all parameters recorded by AMS (Table 1 ), which is in accordance with the results of previous study carried out by the same authors (Waśkowicz et al., 2014; Piwczyński et al., 2020a). While these studies concerned analogous

Table 1. F statistic and significance (marked by ${ }^{*}$ ) of the impact of main factors and interactions on milking parameters.

\begin{tabular}{llll}
\hline Trait & Country (C) & Year (Y) & C XY \\
\hline Average number of robots per herd (no.) & $3845.97^{* *}$ & $21.80^{* *}$ & $40.33^{* *}$ \\
Number of cows per robot (no.) & $200.87^{* *}$ & $7.70^{* *}$ & $4.11^{* *}$ \\
Daily milk yield per robot (kg) & $269.79^{* *}$ & $22.84^{* *}$ & $2.09^{* *}$ \\
Robot free time (\%/24h) & $61.35^{* *}$ & $9.45^{* *}$ & $1.69^{*}$ \\
Average days in milk (days) & $54.96^{* *}$ & 1.92 & $4.22^{* *}$ \\
Daily milking frequency (no./cow) & $204.03^{* *}$ & $4.40^{*}$ & $3.52^{* *}$ \\
Daily number of refusals (no./cow) & $706.13^{* *}$ & 2.24 & $4.85^{* *}$ \\
Daily number of failures (no./cow) & $247.80^{* *}$ & $38.88^{* *}$ & $4.40^{* *}$ \\
Box time (s) & $73.13^{* *}$ & $10.38^{* *}$ & $1.78^{*}$ \\
Milking speed (kg/min) & $410.82^{* *}$ & $40.11^{* *}$ & $1.84^{*}$ \\
Daily milk yield per cow (kg) & $366.22^{* *}$ & $42.62^{* *}$ & $3.14^{* *}$ \\
Milk efficiency (kg/min) & $384.00^{* *}$ & $16.01^{* *}$ & $1.77^{*}$ \\
Fat content (\%) & $148.41^{* *}$ & $3.51^{*}$ & 1.05 \\
Protein content (\%) & $138.19^{* *}$ & $3.14^{*}$ & 0.47 \\
Rumination time (min/24h) & $98.22^{* *}$ & $1044.00^{* *}$ & $3.84^{* *}$ \\
Consumption of concentrated fodder per $100 \mathrm{~kg}$ of milk (kg) & $1767.17^{* *}$ & $47.80^{* *}$ & $5.55^{* *}$ \\
\hline
\end{tabular}

$* \mathrm{P} \leq 0.05, * * \mathrm{P} \leq 0.01$ 
features and countries, they spanned the period of operation from 2012-2017.

In these studies, authors suggested that the differentiation of countries in terms of controlled milk yields, was a result of a different genetic potential of dairy cows. In the present study, as well as in the previous one (Piwczyński et al., 2020a) the statistical influence of milking year and the country $\times$ milking year interaction on most of the analysed features was demonstrated, with the exception of milking year on average daily days in milk and the number of rejected milkings, as well as interaction of country $\times$ year on percentage of fat and protein.

It was found that in the studied countries one farm on the average was equipped with 1.50 (in FR) - 3.32 (US) robots, with the average number of cows per one robot being at the level of 51.49 (NL) - 60.03 (DE) (Table 2). To a large extent, the observed differences can be explained by the different averages of herd sizes in countries included in this study (Piwczyński et al., 2020a). The study showed significant, statistical differentiation of the compared countries in terms of milk yield per robot i.e. from 1351 $\mathrm{kg}$ (LT) up to $1930 \mathrm{~kg}$ (US). At the same time, in 2018-2020 a general upward trend was shown in the number of robots in the herd, the number of cows per milking robot and daily milk yield per robot. This trend is in accordance with the one observed in past studies (Waśkowicz et al., 2014; Piwczyński et al., 2020a). It should be emphasized that a greater control over the herd, in which AMS is installed, may contribute to an increase in the number of cows per one robot without detriment to their health or their efficiency (Castro et al., 2012; Tse et al., 2017). Deming et al. (2013) found that herd performance could be increased by reducing the number of cows per robot and increasing access to the feed table and increasing the amount of provided feed. Tse et al. (2017) emphasize that the introduction of AMS in Canada gave breeders the opportunity to increase the number of cows in the herd (the average number of cows per robot was at the level of 52). It is very important to establish the optimal number of cows per robot. Rodenburg (2017) note that the optimal number of cows in a barn equipped with AMS should be less than 250 animals. On the other hand, Grant and Albright (2001) optimized for an even smaller herd size of less than 100 cows. In their opinion, it is good if animals recognize each other, then they can use AMS without stress. Barman et al. (2017) emphasize that the presence of cows in an unknown group exposes their body to stress, which results in a decrease in milk yield and weight loss. Perhaps, it is not possible to provide a universal and optimal number of cows per robot, and this number is best adjusted individually to each herd.

The results of studies by Castro et al. (2012) proved that the optimal free time of a robot should be about $10 \%$ of the day. In our research, it ranged from $19.00 \%$ (US) to as much as $27.42 \%$ (CZ) (Table 2 ). This presents a potential possibility of a significant increase in the number of cows per one robot, and then the daily milk yield and improving the profitability of production on the farm. One of the herd indicators recorded by AMS is the average lactation day (Table 2). In the present studies, the highest value of this indicator was found in NL (207.7 days), followed by PL (198.8 days), which proves that in these countries' lactation lasted the longest. On the other hand, the shortest lactations were noted in LV (181.7 days) and LT (185.3 days). In the studied herds, cows milked on average 2.71 times a day, the least frequently in FR (2.50 milkings/day), and most often in LV (2.83 milkings/day) and NL (2.82 milkings/day) (Table 2). The obtained results were generally characterized by a growing tendency in the reporting years 2018-2020, exceeding the results presented in previous studies (Waśkowicz et al., 2014; Piwczyński et al., 2020a). In the study by Sitkowska et al. (2020), who investigated primiparas performance, the importance of the average milking frequency (especially in the initial phase of the first lactation) on milk yield in its further stages was demonstrated with levels above 3.50 milkings a day considered optimal. In turn, Castro et al. (2012) found the range between 2.40 and 2.60 a day to be the optimal value of milking frequency per day.

It was found that in the studied countries, the milking robot software limited the animal's ability to undergo milking (refuslas milkings) on average from 1.57 (US) to 3.57 no./day (LT) (Table 3). At the same time, it was observed that the number of failed milkings ranged from 3.84 (FR) to 6.58 no./day (LT). It should be emphasized that in 2018-2020 there was a favorable tendency to reduce failed milkings (from 5.13 no./day to 4.72 no./day). Also the fact that the results presented in the present study were more favorable than those reported previously (Waśkowicz et al., 2014) should also be noted. The frequency of milkings and milking time are the most common indicators of cow's maturity for full production. Castro et al. (2012) found that varying number of cows per robot and the milk speed had the greatest effect on the daily milk yield in AMS. Salfer et al. (2017) emphasised that management system in AMS equipped barns should be properly parameterized in such a way that it makes sure that cows occupy robots at the right time. In AMS, the amount of milk obtained by the robot per day is of key importance in shaping the profitability of production, which is directly related to the amount of milk collected per minute of the time cow spends in the milking stall - milk efficiency $(\mathrm{kg} / \mathrm{min})$. This feature, in turn, is directly dependent on the duration of the cow's stay in the milking stall, milking speed and milk yield, as well as time that is spend on preparing the cow for milking (including robot attachment time). Cows in the barns covered by the study spent on the average $394 \mathrm{~s}$ (IT) to $416 \mathrm{~s}$ (US) in the milking box, gave between 25.17 (LT) and 34.14 $\mathrm{kg}$ of milk (US), with the speed that ranged between $2.30 \mathrm{~kg} / \mathrm{min}$ (LT) and $2.99 \mathrm{~kg} / \mathrm{min}$ (US) (Table 3). The milk efficiency index, calculated for the entire dataset on the basis of this information, equalled $1.59 \mathrm{~kg} / \mathrm{min}$, and ranged in different counties from $1.44 \mathrm{~kg} / \mathrm{min}$ (LV) to $1.77 \mathrm{~kg} / \mathrm{min}$ (US). 
Table 2. Milking parameters according to country and milking year.

\begin{tabular}{|c|c|c|c|c|c|c|c|c|c|c|c|}
\hline \multirow[t]{2}{*}{ Year } & \multirow[t]{2}{*}{ Statistics } & \multicolumn{9}{|c|}{ Country } & \multirow[t]{2}{*}{ Total } \\
\hline & & $C Z$ & $\mathrm{DE}$ & $\mathrm{FR}$ & IT & LT & LV & NL & PL & US & \\
\hline \multicolumn{12}{|c|}{ Average number of robots per herd (no.) } \\
\hline 2018 & $\overline{\mathrm{x}}$ & 2.08 & 1.66 & 1.47 & 1.70 & 2.66 & 1.90 & 1.98 & 1.79 & 3.12 & 2.04 \\
\hline 2019 & $\overline{\mathrm{x}}$ & 2.00 & 1.68 & 1.50 & 1.71 & 2.43 & 1.84 & 2.00 & 1.71 & 3.32 & 2.02 \\
\hline 2020 & $\overline{\mathrm{x}}$ & 1.97 & 1.74 & 1.54 & 1.77 & 2.40 & 1.95 & 2.05 & 1.66 & 3.57 & 2.07 \\
\hline \multirow[t]{4}{*}{ Total } & $\overline{\mathrm{x}}$ & 2.02 & 1.69 & 1.50 & 1.73 & 2.50 & 1.90 & 2.01 & 1.72 & 3.32 & 2.04 \\
\hline & & $A$ & $A B$ & $A B C$ & $A C D$ & $A B C D E$ & $A B C D$ & $\mathrm{BCDE}$ & ACEF & $A B C D$ & \\
\hline & & & & & & & $\mathrm{EF}$ & $\mathrm{FG}$ & $\mathrm{GH}$ & EFGH & \\
\hline & $\mathrm{CV}$ & 2.69 & 2.08 & 1.92 & 2.66 & 6.29 & 4.46 & 1.52 & 3.74 & 5.78 & 26.21 \\
\hline \multicolumn{12}{|c|}{ Number of cows per robot (no.) } \\
\hline 2018 & $\overline{\mathrm{x}}$ & 53.96 & 60.48 & 55.29 & 56.97 & 53.59 & 53.21 & 51.13 & 58.24 & 56.25 & 55.46 \\
\hline 2019 & $\overline{\mathrm{x}}$ & 54.92 & 60.19 & 56.05 & 57.01 & 53.67 & 55.03 & 51.60 & 59.09 & 56.47 & 56.00 \\
\hline 2020 & $\overline{\mathrm{x}}$ & 55.60 & 59.31 & 55.45 & 57.14 & 54.15 & 52.77 & 51.80 & 57.07 & 57.08 & 55.60 \\
\hline \multirow[t]{4}{*}{ Total } & $\overline{\mathrm{x}}$ & 54.78 & 60.03 & 55.60 & 57.03 & 53.78 & 53.72 & 51.49 & 58.19 & 56.57 & 55.69 \\
\hline & & $\mathrm{Aa}$ & $A B$ & $\mathrm{BC}$ & $A B C D b$ & BCDEa & BCDFa & $A B C D$ & $A B C E$ & ABEF & \\
\hline & & & & & & & & EFG & $\mathrm{FGHb}$ & $\mathrm{GH}$ & \\
\hline & CV & 1.78 & 1.52 & 1.91 & 2.24 & 2.26 & 3.33 & 1.69 & 2.38 & 0.89 & 4.85 \\
\hline \multicolumn{12}{|c|}{ Daily milk yield per robot $(\mathrm{kg})$} \\
\hline 2018 & $\overline{\mathrm{x}}$ & 1525 & 1709 & 1572 & 1799 & 1277 & 1424 & 1515 & 1692 & 1908 & 1602 \\
\hline 2019 & $\overline{\mathrm{x}}$ & 1528 & 1714 & 1587 & 1801 & 1376 & 1526 & 1529 & 1775 & 1910 & 1638 \\
\hline 2020 & $\overline{\mathrm{x}}$ & 1588 & 1728 & 1622 & 1860 & 1411 & 1489 & 1547 & 1746 & 1979 & 1663 \\
\hline \multirow[t]{4}{*}{ Total } & $\overline{\mathrm{x}}$ & 1545 & 1716 & 1592 & 1818 & 1351 & 1479 & 1529 & 1737 & 1930 & 1633 \\
\hline & & $\mathrm{Aa}$ & $A B$ & $\mathrm{BCb}$ & $A B C D$ & $A B C D E$ & $\mathrm{BCDE}$ & $\mathrm{BDEGb}$ & ACDE & $A B C D$ & \\
\hline & & & & & & & $\mathrm{Fa}$ & & FGH & EFGH & \\
\hline & CV & 4.08 & 3.04 & 4.70 & 5.25 & 5.82 & 5.74 & 3.12 & 4.10 & 2.64 & 11.33 \\
\hline \multicolumn{12}{|c|}{ Robot free time (\%) } \\
\hline 2018 & $\overline{\mathrm{x}}$ & 28.68 & 21.94 & 26.23 & 27.25 & 28.09 & 22.65 & 26.97 & 20.12 & 18.83 & 24.53 \\
\hline 2019 & $\overline{\mathrm{x}}$ & 27.35 & 21.83 & 25.37 & 27.25 & 24.47 & 23.73 & 25.58 & 19.30 & 19.24 & 23.79 \\
\hline 2020 & $\overline{\mathrm{x}}$ & 26.00 & 21.46 & 24.73 & 26.57 & 23.26 & 22.52 & 24.81 & 19.72 & 18.92 & 23.11 \\
\hline \multirow[t]{3}{*}{ Total } & $\overline{\mathrm{x}}$ & 27.42 & 21.76 & 25.49 & 27.05 & 25.39 & 22.99 & 25.84 & 19.71 & 19.00 & 23.85 \\
\hline & & $A$ & $A B$ & $\mathrm{BCa}$ & $\mathrm{BD}$ & BEb & ADFab & BFG & $\begin{array}{c}\text { ACDE } \\
F G\end{array}$ & $\begin{array}{c}A B C D E \\
F G\end{array}$ & \\
\hline & CV & 6.97 & 6.74 & 12.22 & 10.76 & 10.98 & 11.61 & 9.45 & 11.36 & 7.33 & 15.84 \\
\hline \multicolumn{12}{|c|}{ Average days in milk (days) } \\
\hline 2018 & $\overline{\mathrm{x}}$ & 185.7 & 183.4 & 189.7 & 195.1 & 189.1 & 180.2 & 201.7 & 203.1 & 181.2 & 189.9 \\
\hline 2019 & $\overline{\mathrm{x}}$ & 188.7 & 187.9 & 191.9 & 195.7 & 187.0 & 180.7 & 210.2 & 201.6 & 180.7 & 191.6 \\
\hline 2020 & $\overline{\mathrm{x}}$ & 191.5 & 192.1 & 192.3 & 191.1 & 178.6 & 184.7 & 212.0 & 190.5 & 178.5 & 190.1 \\
\hline \multirow[t]{4}{*}{ Total } & $\overline{\mathrm{x}}$ & 188.5 & 187.6 & 191.2 & 194.1 & 185.3 & 181.7 & 207.7 & 198.8 & 180.2 & 190.6 \\
\hline & & $\mathrm{Aa}$ & B & $\mathrm{Cb}$ & $\mathrm{D}$ & $\mathrm{DE}$ & $\mathrm{aCDF}$ & $A B C D$ & ABEF & $A B C D$ & \\
\hline & & & & & & & & EFG & $\mathrm{GHb}$ & $\mathrm{GH}$ & \\
\hline & CV & 2.16 & 3.17 & 4.86 & 5.19 & 4.72 & 3.79 & 3.14 & 4.48 & 1.35 & 5.76 \\
\hline \multicolumn{12}{|c|}{ Daily milking frequency (no.) } \\
\hline 2018 & $\overline{\mathrm{x}}$ & 2.66 & 2.62 & 2.51 & 2.74 & 2.58 & 2.83 & 2.83 & 2.76 & 2.79 & 2.70 \\
\hline 2019 & $\overline{\mathrm{x}}$ & 2.63 & 2.62 & 2.48 & 2.79 & 2.65 & 2.86 & 2.83 & 2.79 & 2.78 & 2.71 \\
\hline 2020 & $\overline{\mathrm{x}}$ & 2.61 & 2.67 & 2.50 & 2.80 & 2.68 & 2.81 & 2.82 & 2.80 & 2.79 & 2.72 \\
\hline \multirow[t]{3}{*}{ Total } & $\overline{\mathrm{x}}$ & 2.64 & 2.63 & 2.50 & 2.78 & 2.64 & 2.83 & 2.82 & 2.78 & 2.79 & 2.71 \\
\hline & & $A$ & B & $A B C$ & $\mathrm{ABCDa}$ & $\mathrm{CDE}$ & $\begin{array}{c}A B C D \\
E b\end{array}$ & ABCEa & $A B C E b$ & $A B C E b$ & \\
\hline & $\mathrm{CV}$ & 1.84 & 1.80 & 1.55 & 1.55 & 2.62 & 2.42 & 1.76 & 1.39 & 1.29 & 4.40 \\
\hline
\end{tabular}


Table 3. Milking parameters according to country and milking year.

\begin{tabular}{|c|c|c|c|c|c|c|c|c|c|c|c|}
\hline \multirow[t]{2}{*}{ Year } & \multirow[t]{2}{*}{ Statistics } & \multicolumn{9}{|c|}{ Country } & \multirow[t]{2}{*}{ Total } \\
\hline & & $\mathrm{CZ}$ & $\mathrm{DE}$ & $\mathrm{FR}$ & IT & LT & LV & NL & $\mathrm{PL}$ & US & \\
\hline \multicolumn{12}{|c|}{ Daily number of refusals per cow (no.) } \\
\hline 2018 & $\overline{\mathrm{x}}$ & 2.33 & 2.46 & 1.77 & 1.65 & 3.64 & 2.05 & 3.61 & 2.09 & 1.55 & 2.35 \\
\hline 2019 & $\overline{\mathrm{x}}$ & 2.39 & 2.49 & 1.70 & 1.69 & 3.33 & 2.12 & 3.53 & 2.01 & 1.61 & 2.32 \\
\hline 2020 & $\overline{\mathrm{X}}$ & 2.22 & 2.49 & 1.66 & 1.60 & 3.78 & 2.10 & 3.29 & 2.01 & 1.56 & 2.3 \\
\hline \multirow[t]{3}{*}{ Total } & $\overline{\mathrm{x}}$ & 2.32 & 2.48 & 1.71 & 1.65 & 3.57 & 2.09 & 3.49 & 2.04 & 1.57 & 2.32 \\
\hline & & $\mathrm{Aa}$ & $\mathrm{Ba}$ & $A B C$ & $A B D$ & $A B C D E$ & $\begin{array}{c}\mathrm{ABCD} \\
\mathrm{EF}\end{array}$ & ABCDFG & $\mathrm{ABCDEGH}$ & $\begin{array}{c}\text { ABEF } \\
\text { GH }\end{array}$ & \\
\hline & $\mathrm{CV}$ & 5.04 & 2.94 & 6.55 & 6.01 & 9.79 & 6.95 & 8.3 & 6.39 & 5.26 & 31.28 \\
\hline \multicolumn{12}{|c|}{ Daily number of failures per cow (no.) } \\
\hline 2018 & $\overline{\mathrm{x}}$ & 4.62 & 4.38 & 3.95 & 4.76 & 7.19 & 5.78 & 4.36 & 5.99 & 5.13 & 5.13 \\
\hline 2019 & $\overline{\mathrm{x}}$ & 4.68 & 4.32 & 3.93 & 4.58 & 6.33 & 6.00 & 4.41 & 5.57 & 5.39 & 5.02 \\
\hline 2020 & $\overline{\mathrm{x}}$ & 4.49 & 4.03 & 3.61 & 4.14 & 6.21 & 5.83 & 4.16 & 5.25 & 4.78 & 4.72 \\
\hline \multirow[t]{3}{*}{ Total } & $\overline{\mathrm{x}}$ & 4.60 & 4.25 & 3.84 & 4.49 & 6.58 & 5.87 & 4.31 & 5.61 & 5.11 & 4.97 \\
\hline & & $\mathrm{Aa}$ & $a B$ & $A B C$ & $C D$ & $A B C D E$ & $\begin{array}{c}A B C D \\
E F\end{array}$ & CEFG & $\mathrm{ABCDEGH}$ & $\begin{array}{c}\text { ABCDE } \\
\text { FGH }\end{array}$ & \\
\hline & CV & 5.67 & 4.42 & 5.29 & 6.43 & 10.96 & 10.25 & 4.85 & 6.18 & 7.32 & 18.81 \\
\hline \multicolumn{12}{|c|}{ Box time per cow per visit (s) } \\
\hline 2018 & $\overline{\mathrm{x}}$ & 413 & 405 & 424 & 394 & 388 & 400 & 403 & 396 & 419 & 405 \\
\hline 2019 & $\overline{\mathrm{x}}$ & 413 & 405 & 427 & 393 & 399 & 406 & 405 & 402 & 413 & 407 \\
\hline 2020 & $\overline{\mathrm{x}}$ & 418 & 406 & 430 & 396 & 397 & 408 & 410 & 406 & 415 & 410 \\
\hline \multirow[t]{3}{*}{ Total } & $\overline{\mathrm{x}}$ & 415 & 406 & 427 & 394 & 395 & 405 & 406 & 401 & 416 & 407 \\
\hline & & $A$ & $A B$ & $A B C$ & $A B C D a$ & $\mathrm{ABCE}$ & $\begin{array}{c}\mathrm{ACD} \\
\mathrm{EF}\end{array}$ & $\begin{array}{c}\text { ACD } \\
\text { EG }\end{array}$ & $\mathrm{ACHa}$ & $\begin{array}{c}\text { BCDE } \\
\text { FGH }\end{array}$ & \\
\hline & CV & 1.25 & 1.21 & 2.00 & 2.41 & 2.01 & 1.76 & 1.19 & 2.30 & 2.09 & 3.06 \\
\hline \multicolumn{12}{|c|}{ Milking speed (kg/min) } \\
\hline 2018 & $\overline{\mathrm{x}}$ & 2.45 & 2.54 & 2.54 & 2.83 & 2.24 & 2.26 & 2.53 & 2.56 & 2.92 & 2.54 \\
\hline 2019 & $\overline{\mathrm{x}}$ & 2.47 & 2.58 & 2.55 & 2.82 & 2.32 & 2.33 & 2.54 & 2.62 & 3.00 & 2.58 \\
\hline 2020 & $\overline{\mathrm{x}}$ & 2.53 & 2.63 & 2.58 & 2.85 & 2.36 & 2.39 & 2.55 & 2.63 & 3.07 & 2.62 \\
\hline \multirow[t]{3}{*}{ Total } & $\overline{\mathrm{x}}$ & 2.48 & 2.58 & 2.56 & 2.83 & 2.30 & 2.32 & 2.54 & 2.60 & 2.99 & 2.58 \\
\hline & & $A$ & $A B$ & $A C$ & $A B C D$ & $A B C D E$ & $A B C D F$ & DEFG & ADEFH & $A B C D$ & \\
\hline & $\mathrm{CV}$ & 2.52 & 2.66 & 2.19 & 2.05 & 3.78 & 3.83 & 1.97 & 2.51 & 3.23 & 8.50 \\
\hline \multicolumn{12}{|c|}{ Daily milk yield per cow (kg) } \\
\hline 2018 & $\overline{\mathrm{x}}$ & 28.24 & 28.26 & 28.43 & 31.56 & 23.83 & 26.76 & 29.63 & 29.04 & 33.93 & 28.85 \\
\hline 2019 & $\overline{\mathrm{x}}$ & 27.83 & 28.47 & 28.31 & 31.58 & 25.62 & 27.73 & 29.63 & 30.05 & 33.83 & 29.23 \\
\hline 2020 & $\overline{\mathrm{x}}$ & 28.56 & 29.14 & 29.23 & 32.54 & 26.07 & 28.2 & 29.85 & 30.59 & 34.68 & 29.87 \\
\hline \multirow[t]{4}{*}{ Total } & $\overline{\mathrm{X}}$ & 28.20 & 28.61 & 28.65 & 31.89 & 25.17 & 27.56 & 29.70 & 29.89 & 34.14 & 29.28 \\
\hline & & $A$ & B & $C$ & $A B C D$ & $A B C D E$ & BCDEF & $A B C D E F G$ & $A B C D$ & $A B C D$ & \\
\hline & & & & & & & & & EFH & EFGH & \\
\hline & $\mathrm{CV}$ & 2.89 & 2.37 & 3.20 & 3.49 & 4.98 & 4.10 & 1.72 & 3.05 & 2.11 & 8.86 \\
\hline \multicolumn{12}{|c|}{ Milk efficiency (kg/min.) } \\
\hline 2018 & $\overline{\mathrm{x}}$ & 1.54 & 1.60 & 1.60 & 1.75 & 1.42 & 1.42 & 1.56 & 1.59 & 1.74 & 1.58 \\
\hline 2019 & $\overline{\mathrm{x}}$ & 1.54 & 1.61 & 1.60 & 1.73 & 1.45 & 1.43 & 1.55 & 1.61 & 1.77 & 1.59 \\
\hline 2020 & $\overline{\mathrm{x}}$ & 1.57 & 1.61 & 1.63 & 1.76 & 1.47 & 1.48 & 1.55 & 1.62 & 1.80 & 1.61 \\
\hline \multirow[t]{3}{*}{ Total } & $\overline{\mathrm{x}}$ & 1.55 & 1.61 & 1.61 & 1.75 & 1.45 & 1.44 & 1.55 & 1.61 & 1.77 & 1.59 \\
\hline & & $A$ & $A B$ & $A C$ & $A B C D$ & $A B C D E$ & $A B C D F$ & $\begin{array}{c}\text { BCDE } \\
\text { FG }\end{array}$ & $\begin{array}{c}\text { ADEF } \\
\text { GH }\end{array}$ & $\begin{array}{c}\text { ABCEF } \\
\text { GH }\end{array}$ & \\
\hline & CV & 2.19 & 2.09 & 2.19 & 2.16 & 2.95 & 2.96 & 2.30 & 1.87 & 2.49 & 7.09 \\
\hline
\end{tabular}

CV - coefficient of variation (\%); CZ - Czech Republic, FR - France, DE - Germany, IT - Italy LV - Latvia, LT - Lithuania, NL - Netherlands, PL Poland, US - United States

AA (aa) - Values that are significantly different within a variable are marked with the same letters $P \leq 0.01(P \leq 0.05)$ 
It is significant that the presented results regarding milking speed, milk yield and milk efficiency indicate a favourable upward trend in years 2018-2020, which is a continuation of the previously studied period of years 2012-2017 (Waśkowicz et al., 2014; Piwczyński et al., 2020a).

When analysing the chemical composition of milk, it was observed that the highest fat (4.39\%) and protein (3.55\%) contents were found in milk obtained from cows in NL (Table 4). On the other hand, the lowest level of fat was recorded in milk in IT (3.84\%), and proteins in US (3.11\%). The studies showed a significant influence of the milking year on the analysed characteristics of milk composition (Table 1), but the changes in their level in the following years did not express any clear trend. Also, the currently presented results in this respect were similar to those obtained in previous studies (Waśkowicz et al., 2014; Piwczyński et al., 2020a).

Salfer et al. (2017) noted yet another important benefit for AMS farms, namely pelleted feed supplementation in AMS box was strongly associated with body condition and thus might cause the increase in milk production. When analysing the rumination activity of cows (measured by the number of minutes per day), it was found that rumination time was the shortest in the US (468.99 minutes), and the longest in the LV (504.86 minutes) (Table 4). The amount of concentrated feed intake depends on many factors, including the palatability of the feed and the individual requirements of a cow. The analysis showed that a cow for the production of $100 \mathrm{~kg}$ of milk consumed from $12.96 \mathrm{~kg}$ (IT) to $20.05 \mathrm{~kg}$ (NL) of concentrate feed.

Table 4. Milking parameters according to country and milking year.

\begin{tabular}{|c|c|c|c|c|c|c|c|c|c|c|c|}
\hline \multirow[t]{2}{*}{ Year } & \multirow[t]{2}{*}{ Statistics } & \multicolumn{9}{|c|}{ Country } & \multirow[t]{2}{*}{ Total } \\
\hline & & $\mathrm{CZ}$ & $\mathrm{DE}$ & $\mathrm{FR}$ & IT & $\mathrm{LT}$ & LV & $\mathrm{NL}$ & $\mathrm{PL}$ & US & \\
\hline \multicolumn{12}{|c|}{ Fat content (\%) } \\
\hline 2018 & $\overline{\mathrm{x}}$ & 3.95 & 4.04 & 4.09 & 3.83 & 4.18 & 3.95 & 4.37 & 3.91 & 3.87 & 4.02 \\
\hline 2019 & $\overline{\mathrm{x}}$ & 4.00 & 4.10 & 4.17 & 3.86 & 4.11 & 3.96 & 4.41 & 3.92 & 3.90 & 4.05 \\
\hline 2020 & $\overline{\mathrm{x}}$ & 3.96 & 4.09 & 4.16 & 3.84 & 4.14 & 3.95 & 4.39 & 3.97 & 3.89 & 4.04 \\
\hline \multirow[t]{4}{*}{ Total } & $\overline{\mathrm{x}}$ & 3.97 & 4.07 & 4.14 & 3.84 & 4.14 & 3.96 & 4.39 & 3.93 & 3.88 & 4.04 \\
\hline & & $\mathrm{Aa}$ & $A B$ & $A C$ & $A B C D$ & $\mathrm{ADE}$ & BCDEF & $A B C D E$ & $\mathrm{BCD}$ & $\mathrm{BCE}$ & \\
\hline & & & & & & & & FG & EG & $\mathrm{Ga}$ & \\
\hline & CV & 2.22 & 2.17 & 2.10 & 1.45 & 1.93 & 2.38 & 2.31 & 1.26 & 1.95 & 4.44 \\
\hline \multicolumn{12}{|c|}{ Protein content (\%) } \\
\hline 2018 & $\overline{\mathrm{x}}$ & 3.40 & 3.43 & 3.32 & 3.38 & 3.37 & 3.29 & 3.53 & 3.38 & 3.11 & 3.36 \\
\hline 2019 & $\overline{\mathrm{X}}$ & 3.43 & 3.45 & 3.36 & 3.40 & 3.36 & 3.33 & 3.56 & 3.37 & 3.12 & 3.38 \\
\hline 2020 & $\overline{\mathrm{x}}$ & 3.39 & 3.44 & 3.35 & 3.39 & 3.35 & 3.29 & 3.55 & 3.37 & 3.11 & 3.36 \\
\hline \multirow[t]{4}{*}{ Total } & $\overline{\mathrm{x}}$ & 3.41 & 3.44 & 3.34 & 3.39 & 3.36 & 3.30 & 3.55 & 3.37 & 3.11 & 3.36 \\
\hline & & $\mathrm{Aa}$ & $B$ & $\mathrm{BCa}$ & $D$ & $\mathrm{BEb}$ & ABDFb & $A B C D$ & BFGH & ABCDEF & \\
\hline & & & & & & & & $\mathrm{EFG}$ & & $\mathrm{GH}$ & \\
\hline & $\mathrm{CV}$ & 1.90 & 1.73 & 1.77 & 1.37 & 1.65 & 2.06 & 1.73 & 0.76 & 1.97 & 3.66 \\
\hline \multicolumn{12}{|c|}{ Rumination time (min./24h) } \\
\hline 2018 & $\overline{\mathrm{x}}$ & 462.2 & 470.0 & 474.4 & 456.2 & 474.6 & 483.9 & 476.9 & 470.3 & 446.3 & 468.3 \\
\hline 2019 & $\overline{\mathrm{x}}$ & 491.8 & 485.6 & 500.0 & 476.7 & 482.8 & 501.7 & 498.8 & 490.9 & 472.3 & 489.0 \\
\hline 2020 & $\overline{\mathrm{x}}$ & 507.0 & 505.6 & 516.2 & 502.0 & 507.5 & 528.9 & 521.3 & 510.5 & 488.3 & 509.7 \\
\hline \multirow[t]{4}{*}{ Total } & $\overline{\mathrm{X}}$ & 487.03 & 487.06 & 496.87 & 478.28 & 488.31 & 504.86 & 499.02 & 490.58 & 468.99 & 487.8 \\
\hline & & A & B & $\mathrm{ABCa}$ & $A B C D$ & CDE & $A B C D$ & ABDEG & DFGHa & ABCDEF & \\
\hline & & & & & & & EF & & & $\mathrm{GH}$ & \\
\hline & CV & 4.03 & 3.09 & 3.65 & 4.16 & 3.18 & 3.98 & 3.80 & 3.49 & 3.99 & 4.23 \\
\hline \multicolumn{12}{|c|}{ Consumption of concentrated fodder per $100 \mathrm{~kg}$ of milk (kg) } \\
\hline 2018 & $\overline{\mathrm{X}}$ & 16.07 & 14.41 & 14.14 & 12.73 & 16.87 & 13.92 & 20.44 & 14.59 & 14.88 & 15.34 \\
\hline 2019 & $\overline{\mathrm{x}}$ & 15.99 & 14.18 & 14.18 & 13.12 & 16.78 & 13.79 & 20.05 & 14.28 & 14.68 & 15.23 \\
\hline 2020 & $\overline{\mathrm{x}}$ & 15.36 & 13.84 & 14.05 & 13.03 & 16.11 & 13.91 & 19.67 & 14.01 & 14.46 & 14.94 \\
\hline \multirow[t]{4}{*}{ Total } & $\overline{\mathrm{X}}$ & 15.81 & 14.14 & 14.12 & 12.96 & 16.59 & 13.87 & 20.05 & 14.29 & 14.67 & 15.18 \\
\hline & & $A$ & $A B$ & $A C$ & $A B C D$ & $A B C D E$ & ADEF & $A B C D$ & ADEF & $A B C D E F$ & \\
\hline & & & & & & & & EFG & $\mathrm{GH}$ & $\mathrm{GH}$ & \\
\hline & CV & 2.20 & 1.75 & 1.92 & 1.99 & 3.89 & 2.88 & 2.14 & 1.89 & 1.49 & 13.46 \\
\hline
\end{tabular}


The average consumption of concentrate was at the level of $15.18 \mathrm{~kg}$. It should be emphasized that in the years 2018-2020, the average rumination time increased (by 41.4 minutes), while the amount of concentrated feed needed for the production of $100 \mathrm{~kg}$ of milk decreased (by $0.4 \mathrm{~kg}$ ). It is particularly interesting as during this time the daily milk yield of a cow increased by more than $1 \mathrm{~kg}$. This means that breeders in order to satisfy the nutritional needs of cows, instead of concentrate feed, introduced a larger amount of roughage, as evidenced by the longer rumination time. Endres and Salfer (2015), emphasized that in order to obtain the highest milk yield in AMS farms farmers, apart from introducing high-production cows and reducing box time, should also focus on providing good nutritional management.

When analysing the calculated coefficients of variation (CV) of the controlled features according to country, it should be emphasized that they showed a tendency to express low values - in most cases they did not exceed $5 \%$. This proves a significant unification of the parameter values in the subsequent months of data reporting.

\section{Conclusion}

Summing up the results of the conducted research, it should be stated that the tested milking parameters were highly significantly influenced by the country where the milking robot was located. The presumptive reason for these differences was the differentiation of the genetic potential of milked cows and the diversity of the feed base. The research showed that the most favourable results in terms of financial efficiency of a farm (milk speed, milk yield, milk efficiency, robot yield) were found in US and IT herds. In years 2018-2020, a favourable trend was observed in terms of the abovementioned features.

\section{References}

Barman, D., Prasad, K., Kumar, S., Ahirwar, M., Saini M., \& Kamboj, M. L. (2017). Effect of shifting animals from groups on their social relationship and performance. International Journal of Current Microbiology and Applied Sciences, 67, 1601-1606. https://doi.org/ 10.20546/ijcmas.2017.607.193

Brzozowski, M. Piwczyński, D., Sitkowska, B., \& Kolenda, M. (2018). The impact of installation of automatic milking system on production and reproduction traits of dairy cows. Reproduction in Domestic Animals, 53(5), 11231129. https://doi.org/10.1111/rda.13214

Bogucki, M., Sawa, A., \& Neja, W. (2014). Effect of changing the cow's milking system on daily yield and cytological quality of milk. Acta Scientiarum Polonorum, Zootechnica, 13(4), 17-26.

Castro, A., Pereira, J. M., Amiama, C., \& Bueno J. (2012). Estimating efficiency in automatic milking https://doi.org/10.3168/jds.2010-3912

Czerniawska-Piątkowska, E., Gralla, K., Szewczuk, M., \& Chociłowicz, E. (2012). The comparison of yield, composition and quality of cow milk depending on twice-a-day and four-times-a-day milking. Acta Scientiarum Polonorum, Zootechnica, 11(4), 2130.http://agro.icm.edu.pl/agro/element/bwmeta1.el ement.agro-c4600b0d-8d1a-4019-98b8f2f261675c1c/c/ 03-3.pdf

de Koning, K., \& Van der Vorst, Y. (2002). Automatic milking - Changes and changes In Proceedings of the British Mastitis Conference, Brockworth, United Kingdom, 68-80. https://citeseerx.ist.psu. edu/viewdoc/download? doi=10.1.1.583.7769\&rep=rep1\&type=pdf

de Koning, K. (2010). Automatic Milking - Common Practice on Dairy Farms, In Proceedings of the First North American Conference on Precision Dairy Management, Toronto, Ontario, Canada, 52-67. http://precisiondairy.com/proceedings/s3dekoning.p df

Deming, J.A., Bergeron, R., Leslie, K.E., \& DeVries, T.J. (2013) Associations of housing, management, milking activity, and standing and lying behavior of dairy cows milked in automatic systems. Journal of Dairy Science, 96(1), 344-351. https://doi.org/ 10.3168/ jds.2012-5985

Endres, M. I., \& Salfer, J. A. (2015) An evaluation of automated milking systems in the Midwest United States. Journal Dairy Science, 98(Suppl. 2), 114 (Abstract). https://doi.org/10.1016/S0022-0302(20) 30760-8

Grant, R.J., \& Albright, J.L. (2001). Effect of animal grouping on feeding behavior and intake of dairy cattle. Journal of Dairy Science, 84(E. Suppl.), E156-E163. https://doi.org/10.3168/jds.S0022-0302(01) 70210-X

Lely International (2019). Retrieved on 30 October 2019, from personal message.

Nixon, M., Bohmanova, J., Jamrozik, J., Schaeffer, L.R., Hand, K., \& Miglior, F. (2009). Genetic parameters of milking frequency and milk production traits in Canadian Holsteins milked by an automated milking system. Journal of Dairy Science, 92, 3422-3430. https://doi.org/10.3168/jds.2008-1689

Österman, S., Östensson, K., Svennersten-Sjaunja, K., \& Bertilsson, J. (2005). How does extended lactation in combination with different milking frequencies affect somatic cell counts in dairy cows? Livestock Production Science, 96(2), 225-232. https://doi.org/10.1016/ j.livprodsci.2005.01.014

Piwczyński, D., Gondek, J., Sitkowska, B., \& Kolenda, M. (2020a). Comparison of results coming from automatic milking system in selected countries in Europe and U.S. Journal of Central European Agriculture, 21(2), 187196. https://doi.org/ 10.5513/JCEA01/21.2.2559

Piwczyński, D., Brzozowski, M., \& Sitkowska, B. (2020b). The impact of the installation of an automatic milking system on female fertility traits in Holstein-Friesian cows. Livestock Science, 240 https://doi.org/10.1016/j.livsci. 2020.104140

Rodenburg, J. (2017). Robotic milking: Technology, farm design, and effects on work flow. Journal of Dairy Science, 100(9), 7729-7738. https://doi.org/ 10.3168/ jds.2016-11715.

Rotz, C., Coiner, C., \& Soder, K., (2003). Automatic milking systems, farm size, and milk production. Journal of Dairy Science, 86(12), 4167-4177. https://doi.org/10.3168/ jds.S0022-0302(03) 74032-6

SAS Institute Inc.: SAS/STAT ${ }^{\circledR} 94$ User's Guide Cary, NC: SAS Institute Inc. (2014).

Salfer, J. A., Minegishi, K., Lazarus, W., Berning, E., \& Endres, 
M. I. (2017). Finances and returns for robotic dairies. Journal of Dairy Science, 100(9), 7739-7749. https://doi.org/10.3168/jds.2016-11976.

Sitkowska, B., Piwczyński, D., Aerts, J., \& Waśkowicz, M. (2015). Changes in milking parameters with robotic milking. Archives Animal Breeding, 58(1), 1-7. https://doi.org/10.5194/aab-58-137-2015.

Sitkowska, B., Piwczyński, D., Kolenda, M., \& RóżańskaZawieja, J. (2020). The milking frequency of primiparous cows in their early stage of lactation and its impact on milking performance. Animal Production Science, 60(3), 436-443. https://doi.org/10.1071 /AN18409.

Taing, W. (2016). The economic viability of automatic milking systems in Australia's pasture-based dairy farm systems: a case study analysis. Melbourne School of Land and Environment. The University of Melbourne, 1-187. https://minervaaccess.unimelb.edu.au/handle/11343/1 28241.
Tse, C., Barkema H., DeVries T., Rushen J., \& Pajor E. (2017). Effect of transitioning to automatic milking systems on producers' perceptions of farm management and cow health in the Canadian dairy industry. Journal of Dairy Science, 100, 2404-2414. https://doi.org/10.3168/ jds.2016-11521

Waśkowicz, M., Piwczyński, D., Sitkowska, B., \& Aerts, J. (2014) Efektywność stosowania robotów udojowych w wybranych krajach UE i USA [The effectiveness of milking robots in selected EU and US countries]. Przegląd Hodowlany, 6, 27-30. [in Polish] http://ph.ptz. icm.edu.pl/wp-content/uploads/2016/12/3Wa\%C5\%9B kowicz.pdf

Wethal, K. B., \& Heringstad, B. (2019). Genetic analyses of novel temperament and milkability traits in Norwegian Red cattle based on data from automatic milking systems. Journal of Dairy Science, 102(9), 8221-8233. https://doi.org/10.3168/jds.2019-16625 